ISSN 0103-5150

Fisioter. Mov., Curitiba, v. 29, n. 2, p. 351-359, Apr./June 2016

Licenciado sob uma Licença Creative Commons DOI: http://dx.doi.org.10.1590/0103-5150.029.002.A014

\title{
Physical exercise modifies the functional capacity of elderly patients on hemodialysis
}

\author{
Exercício físico modifica a aptidão funcional de idosos \\ em hemodiálise
}

\section{Moane Marchesan ${ }^{[a]}$, Rodrigo de Rosso Krug ${ }^{[a]}$, José Raphael Leandro da Costa e Silva ${ }^{[a]}$, Aline Rodrigues Barbosa ${ }^{[a]}$, Airton José Rombaldi ${ }^{[b] *}$}

[a] Universidade Federal de Santa Catarina (UFSC), Florianópolis, Santa Catarina, Brazil

[b] Universidade Federal de Pelotas (UFpel), Rio Grande do Sul, Brazil

\begin{abstract}
Introduction: Patients on hemodialysis (HD) improve functional capacity after physical training. However, little is discussed about these effects in elderly patients, since these are usually excluded of studies, due to their physical disabilities and other deficits. Objective: To analyze the effects of aerobic and resistance training in the functional capacity of elderly patients submitted to HD. Methods: Studied participants were 15 patients, of both genders, and aged over 60 years. Aerobic and resistance training was carried out during the hemodialysis session, three times per week, during four months. Patients were distributed into control (CG) and experimental (EG) groups. Functional capacity was assessed by six-minute walk (6MW), sit-to-stand (STS) and respiratory muscle strength tests. Results: After the physical training, EG presented a significant increase in the distance covered in $6 \mathrm{MW}(\mathrm{Z}=2.521, \mathrm{p}<.012)$, respiratory muscle strength (inspiratory pressure: $\mathrm{Z}=2.533, \mathrm{p}<.011$; expiratory pressure: $\mathrm{Z}=2.536$,
\end{abstract}

\footnotetext{
*MM: Doctoral student, e-mail: moedfisio@hotmail.com RRK: Doctoral student, e-mail: rodkrug@bol.com.br JRLCS: MSc student, e-mail: profraphaelcosta@hotmail.com ARB: PhD, e-mail: alinerb13@hotmail.com AJR: PhD, e-mail: rombaldi@ufpel.tche.br
} 
$\mathrm{p}<.011)$; and in number of STS repetitions (2.54; $\mathrm{p}<.001)$. Conclusion: The training modified the functional capacity of the HD patients, contributing to their rehabilitation.

Keywords: Chronic renal insufficiency. Exercise. Renal dialysis. Physical fitness.

\section{Resumo}

Introdução: Pacientes em hemodiálise (HD) melhoram sua aptidão funcional após o treinamento físico. Porém, pouco se discute sobre esses efeitos em pacientes idosos, sendo que esses geralmente são excluídos dos estudos, por apresentarem debilidades físicas e demais déficits. Objetivo: Analisar os efeitos do treinamento aeróbio e contra resistência sobre a aptidão funcional de pacientes idosos submetidos à HD. Materiais e Métodos: Participaram deste estudo 15 pacientes, de ambos os sexos, com idade superior a 60 anos. Foi realizado treinamento aeróbio e contra resistência, durante a sessão de HD, três vezes/semana, por 24 semanas. Os pacientes foram divididos em grupo controle (GC) e experimental (GE). A avaliação da aptidão funcional foi feita através dos testes de seis minutos de caminhada (T6), de sentar e levantar (TSL) e de força muscular respiratória. Resultados: Após o treinamento físico o GE apresentou aumento significativo na distância percorrida no T6 (Z $=2.521 ; p<.012$ ), na força muscular respiratória (pressão inspiratória: $Z=2.533 ; p<.011$; pressão expiratória: $Z=2.536 ; p<.011)$; e no número de repetições no TSL (2.54; $p<.001)$. Conclusão: $O$ treinamento utilizado modificou a aptidão funcional dos pacientes, contribuindo na reabilitação destes.

Palavras-chave: Insuficiência renal crônica. Exercício físico. Diálise renal. Aptidão física.

\section{Introduction}

The number of older people is increasingly growing worldwide. Added to this growth is the increased number of chronic diseases (1), such as chronic kidney disease (CKD) (2). CKD is characterized by progressive, irreversible loss of kidney function and, in its most advanced stage (stage $\mathrm{V}$ ), renal replacement therapy is indispensable, so that the body maintains its balance levels (3).

In Brazil, the treatment method commonly used by patients in stage $\mathrm{V}$ is hemodialysis (HD) and a higher prevalence, about $30 \%$ of dialysis patients, is in the age range of 65 years or older (2). Patients on HD usually exhibit decreased functional capacity due to metabolic and physiological changes $(4,5)$.

Anemia, imbalance in the body homeostasis (6), reduction of approximately $50 \%$ of maximal oxygen consumption and $30 \%$ to $40 \%$ of muscle strength, compared to the values found in healthy subjects, lead to decreased muscle functionality and cardiorespiratory capacity. These are cited as some of the complications in physical fitness in this population (4), leading to decreased exercise capacity.

One way to maintain satisfactory response to effort and daily activities is to insert physical exercise into the routine of HD patients. Studies point out that an exercise program can maintain and, even increase the variables of functional capacity in dialysis patients (7).

Therefore, stimulating and encouraging elderly HD patients to perform physical exercise seems to contribute for their rehabilitation since, in addition to increasing exercise capacity, it also improves their perception of quality of life $(5,8,9,10)$.

Despite the arguments cited above, intervention programs and research with this population in Brazil are still rare and, those that exist, often are not conducted exclusively with elderly subjects $(11,12,13)$, as they are more unstable and impaired. Thus, the aim of this study was to analyze the effects of an exercise program on the functional capacity of elderly HD patients.

\section{Materials and Method}

Study design

This was an experimental study whose data were collected in 2009, and which was part of a master dissertation from the Graduate Program in Physical Education, of the Federal University of Pelotas, entitled "Effects of physical exercise for patients submitted to hemodialysis". 
Population and sample

The study sample consisted of 15 patients submitted to HD in the Renal Clinic at Santa Lucia Hospital, in Cruz Alta city, in the state of Rio Grande do Sul. Among patients who were in dialysis treatment in this unit ( $\mathrm{n}=72), 49$ were excluded for being in HD for less than three months, having a central catheter, being under 60 years old, having severe heart disease, respiratory problems, and not having been released by the physician to participate in the program, due to unstable clinical conditions. Unstable medical conditions encompassed biochemical aspects, weight gain on the opposite dialysis day, uncontrolled anemia and the number of complications and hospitalizations in the last six months.

Out of 23 selected patients, five refused to participate, remaining 18 who were randomly divided into a control group (CG) and an experimental group (EG). Three patients were lost, due to hospitalization (CG-n = 1; EG-n = 1) and death (GC-n $=1$ ). None of these losses was associated with exercise. The EG performed the exercise program, which will be described later, and the CG did not. At the end of the intervention, patients in the CG were invited to participate in the exercise program proposed by the researchers.

\section{Ethical aspects}

The research proposal was approved by the Ethics Committee of the School of Physical Education at the Federal University of Pelotas (n. 098/2009). All patients were informed about the procedures of the research and signed a free and informed consent form.

\section{Instruments}

Clinical and sociodemographic characteristics evaluation

These variables were collected by means of an anamnesis of the patients. Sociodemographic characteristics (sex, age, skin color, marital status) were evaluated using a structured questionnaire. Clinical aspects (time of hemodialysis and etiology of the disease) were collected from medical records. Systemic arterial pressure and heart rate were also measured.
Functional capacity evaluation

The evaluation of functional capacity of the patients was carried out before and after training. The variables and their respective instruments were:

a) Functional capacity: evaluated by a six-minute walk (6MW) test, using methodology proposed by Brazilian standardization, in which patients are oriented to cover the longest possible distance in a period of six minutes (14).

b) Resistance of lower limb muscles: evaluated by a sit-to-stand test (STS). The patient was instructed to rise from a chair and go back to sitting position, as fast as possible, in an interval of 30 seconds. The maximum number of repetitions within the established time was recorded (15).

c) Respiratory muscle strength: measured by inspiratory maximum pressures (MIP) and expiratory maximum pressures (MEP), using a scaled manometer in - 300 to $+300 \mathrm{~cm} \mathrm{H}_{2} \mathrm{O}$ (Famabras, Brazil). The Black and Hyatt protocol (16) was used, in which patients remain seated, with nostrils occluded by a nose clip. Three maximal inhalation and exhalations were collected, and the mean among them was considered.

The evaluation of the functional capacity of patients was carried out in a room in the Renal Clinic at Santa Lucia Hospital, in city of Cruz Alta, Rio Grande do Sul, by means of a $6 \mathrm{MW}$ test in a 100 -m corridor properly marked from 10 to 10 meters. These evaluations occurred on opposite days to the ones of HD.

\section{Physical exercises program}

The physical exercise program consisted of aerobic training in a stationary bicycle, followed by resistance exercises for upper and lower limbs, thorax, abdomen and the posterior region of the trunk (Table - 1).

The abdominal muscles were worked isometrically, combined to deep inspiration and expiration exercises. Since the program was carried out during $\mathrm{HD}$, patients were instructed to remain seated, with the fistula arm as still as possible, so there was no damage to the arteriovenous access. 
Table 1- Description of the physical exercises performed during the intervention program

\begin{tabular}{|c|c|c|c|}
\hline $\begin{array}{l}\text { Physical } \\
\text { exercise } \\
\text { modality }\end{array}$ & Instrument & $\begin{array}{c}\text { Exercise } \\
\text { description }\end{array}$ & $\begin{array}{l}\text { Exercised } \\
\text { muscle }\end{array}$ \\
\hline $\begin{array}{l}\text { Aerobic } \\
\text { training }\end{array}$ & $\begin{array}{l}\text { Stationary } \\
\text { bicycle }\end{array}$ & Cycling & $\begin{array}{l}\text { Quadriceps } \\
\text { and abdomen }\end{array}$ \\
\hline \multirow{3}{*}{$\begin{array}{l}\text { Resistance } \\
\text { training }\end{array}$} & \multirow{3}{*}{ Shin pad } & $\begin{array}{c}\text { Knee } \\
\text { extension }\end{array}$ & Quadriceps \\
\hline & & Knee flexion & Ischiotibial \\
\hline & & $\begin{array}{l}\text { Hip } \\
\text { adduction }\end{array}$ & Hip adductors \\
\hline \multirow{9}{*}{$\begin{array}{l}\text { Resistance } \\
\text { training }\end{array}$} & \multirow[b]{2}{*}{ Shin pad } & $\begin{array}{c}\text { Hip } \\
\text { abduction }\end{array}$ & Hip abductors \\
\hline & & $\begin{array}{c}\text { Plantar/ } \\
\text { dorsal } \\
\text { flexion }\end{array}$ & $\begin{array}{c}\text { Soleus, } \\
\text { Gastrocnemius } \\
\text { and fibular }\end{array}$ \\
\hline & \multirow{5}{*}{ Dumbbells } & Direct curl * & Biceps \\
\hline & & $\begin{array}{c}\text { Triceps } \\
\text { extension to } \\
\text { forehead * }\end{array}$ & Triceps \\
\hline & & $\begin{array}{c}\text { Side lateral } \\
\text { raise* }^{\star}\end{array}$ & Deltoid \\
\hline & & $\begin{array}{c}\text { Crucifix } \\
\text { shoulder* }\end{array}$ & Pectoral \\
\hline & & Rowing* & $\begin{array}{l}\text { Latissimus } \\
\text { dorsi and } \\
\text { serratus }\end{array}$ \\
\hline & $\begin{array}{l}\text { Without } \\
\text { instrument - } \\
\text { Isometry }\end{array}$ & Abdominal & Abdomen \\
\hline & Manovacuometer & $\begin{array}{l}\text { Exhalation } \\
\text { and } \\
\text { Inhalation }\end{array}$ & $\begin{array}{c}\text { Abdomen and } \\
\text { diaphragm }\end{array}$ \\
\hline
\end{tabular}

Note:* Exercises performed only in the opposite side of arteriovenous fistula

The thoracic region was exercised by isometric abs, exercise for the chest (crucifix), and rowing, in which the patient was asked to lean forward to take the elbow further from the body midline. The ankle exercises were carried out with the aid of a step, where the patient's tiptoe was supported to perform flexion and extension exercises.

This program had a frequency of three times a week and lasted for 24 weeks. The duration of each exercise session was 45 minutes initially, gradually increasing over time. The prescription of exercises is described in Figure 1, and it has been previously published (17). To evaluate the intensity of the exercises, heart rate (18) and Borg's perceived exertion scale (19) were used.
This scale was chosen, since some patients were taking beta-blockers, which inhibit the heart rate response.

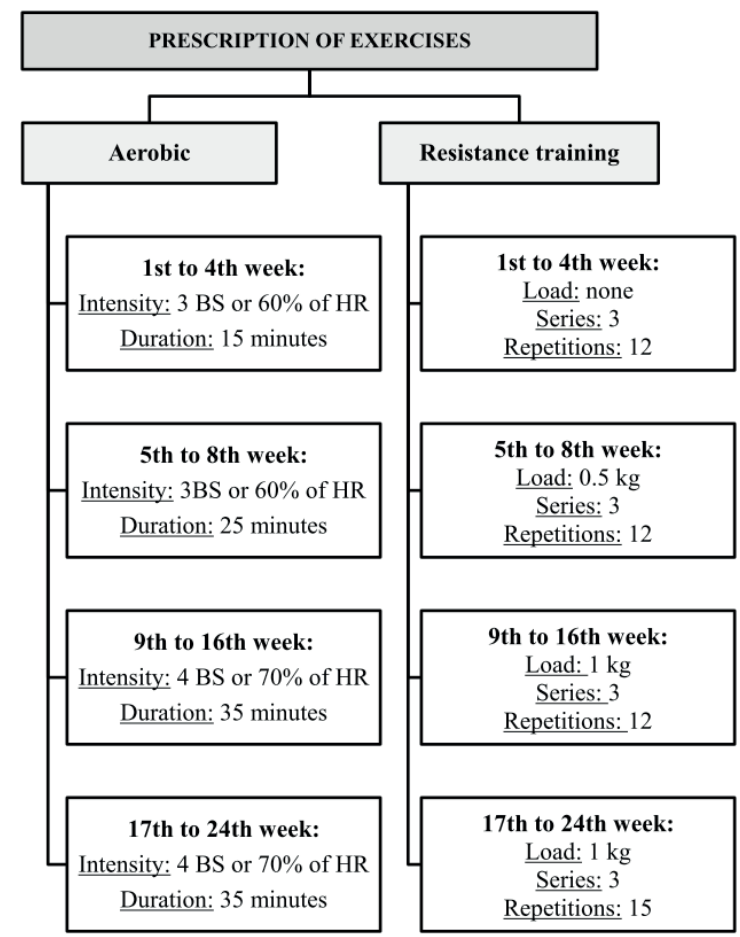

Legend: $\mathrm{BS}=$ Borg Scale; $\%$ = percentage; $\mathrm{HR}=$ Heart rate; $\mathrm{kg}=$ Kilogram . Figure 1 - Physical exercises prescription. Source: Marchesan and Rombaldi (17)

\section{Statistics Analysis}

Data normality was tested by the Shapiro-Wilk test. As the sample did not present a normal distribution, U-Mann Whitney test was used to compare the differences between groups (CG versus EG) before the exercise program and paired samples were compared between, before and after the exercise program in both groups by the Wilcoxon test. Descriptive statistics were utilized for the sample characterization. The software SPSS ${ }^{\circledR}$ version 16.0 was used in data analysis.

\section{Results}

Of 9 patients selected for the intervention, only $1 \mathrm{did}$ not complete the minimum period of participation (adherence of $80 \%$ ). Table -2 shows the characteristics of the HD patients participating in the study with respect to sociodemographic variables. It can be observed that, in both 
groups, most patients were male, of white skin color, and lived accompanied. In clinical aspects, both in the CG and in the EG, the HD period was superior to 12 months and prevalent causes of CKD were hypertension and diabetes.

Patients data regarding functional capacity are exposed in Table 3, for both groups in the beginning of the training. Comparing variables of the $\mathrm{CG}$ with those of the EG, no significant differences were observed before training, indicating homogeneity between groups.

The functional capacity of the EG participants presented a significant difference after training. No patient presented any type of complication during or after the exercise program. There was a significant increase in the covered distance at $6 \mathrm{MW}(\mathrm{Z}=2.52$; $p<.012)$, number of STS repetitions $(Z=2.54$; $\mathrm{p}<.001$ ) and respiratory muscle strength (MIP: $Z=2.53$; $\mathrm{p}<.011 ; \mathrm{MEP}: \mathrm{Z}=2.54 ; \mathrm{p}<.011$ ), as shown in Figure 2.

Table 2 - Sociodemographic characteristics of the sample in the beginning of the physical exercise program. Cruz Alta, Rio Grande do Sul, 2010

\begin{tabular}{|c|c|c|}
\hline Variables & $\begin{array}{c}\text { Control } \\
\text { Group \% (n) }\end{array}$ & $\begin{array}{c}\text { Experimental } \\
\text { Group \% (n) }\end{array}$ \\
\hline \multicolumn{3}{|l|}{ Sociodemographic } \\
\hline \multicolumn{3}{|l|}{ Sex } \\
\hline Male & $71.43(5)$ & $75.00(6)$ \\
\hline Female & $28.57(2)$ & $25.00(2)$ \\
\hline \multicolumn{3}{|l|}{ Skin Color } \\
\hline White & $85.71(6)$ & $75.00(6)$ \\
\hline Other & $14.29(1)$ & $25.00(2)$ \\
\hline \multicolumn{3}{|l|}{ Marital Status } \\
\hline Lives alone & $14.29(1)$ & $37.50(3)$ \\
\hline Lives accompanied & $85.71(6)$ & $62.50(5)$ \\
\hline \multicolumn{3}{|l|}{ Clinical Aspects } \\
\hline \multicolumn{3}{|l|}{ HD period } \\
\hline Six to 12 months & - & $25.00(2)$ \\
\hline More than 12 months & $100.00(7)$ & $75.00(6)$ \\
\hline \multicolumn{3}{|l|}{ Etiology } \\
\hline Hypertension & $57.15(4)$ & $50.00(4)$ \\
\hline Diabetes & $42.85(3)$ & $37.50(3)$ \\
\hline Others & - & $12.50(1)$ \\
\hline \multicolumn{3}{|l|}{ Lifestyle } \\
\hline \multicolumn{3}{|c|}{ Smoking in the last 12 months } \\
\hline Yes & $0(0)$ & $0(0)$ \\
\hline No & $100(7)$ & $100(8)$ \\
\hline \multicolumn{3}{|c|}{ Regular physical exercise in the last six months } \\
\hline Yes & $0(0)$ & $0(0)$ \\
\hline No & $100(7)$ & $100(8)$ \\
\hline
\end{tabular}

Note: legend: $\%=$ percentage; $n=$ sample size; $H D=$ Hemodialysis
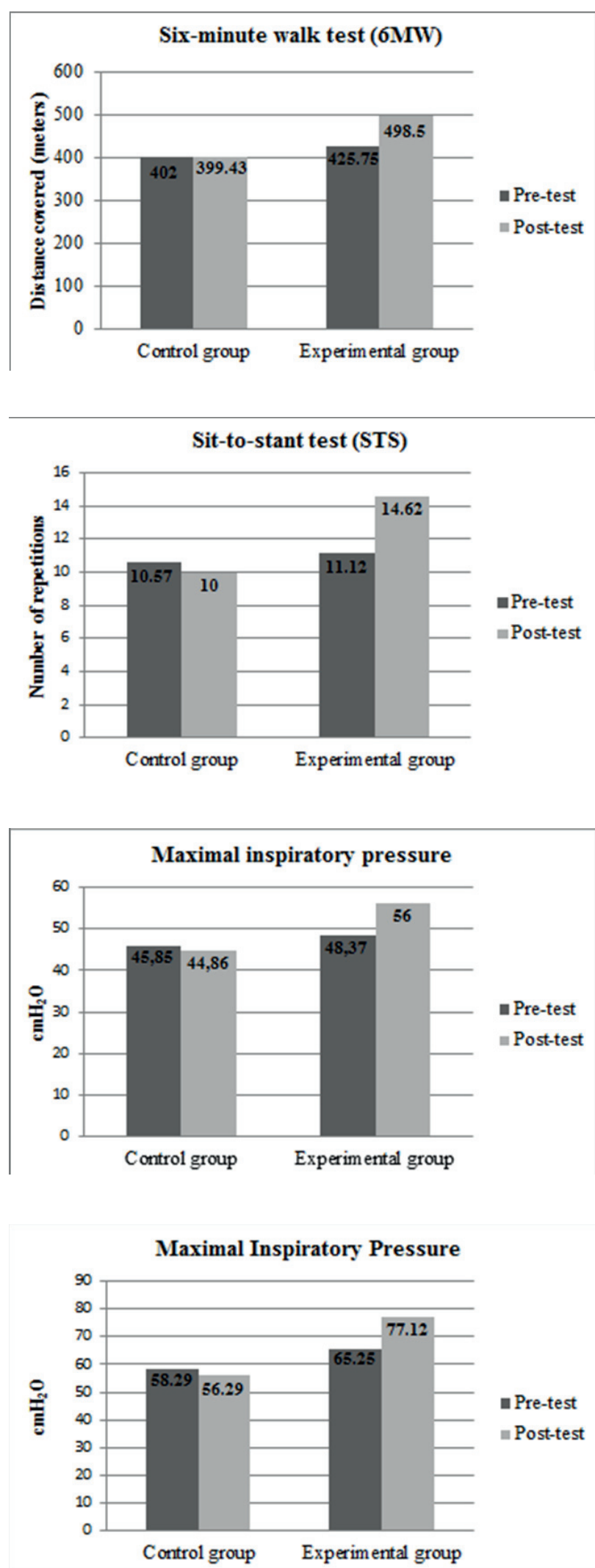

Note: Legend: $\mathrm{cmH} 2 \mathrm{O}=$ centimeters of water; $\mathrm{p}=$ significance level in Wilcoxon test.

Figure 2 - Results of functional capacity of elderly HD patients, after the physical exercise program. Cruz Alta, Rio Grande do Sul, 2010 
Table 3- Sample characterization with data from the beginning of the physical exercise program. Cruz Alta, Rio Grande do Sul, 2010.

\begin{tabular}{|c|c|c|c|c|c|c|c|}
\hline & \multicolumn{3}{|c|}{$\begin{array}{c}\text { Control group } \\
\mathrm{n}=7\end{array}$} & \multicolumn{3}{|c|}{$\begin{array}{l}\text { Experimental group } \\
\qquad \mathrm{n}=8\end{array}$} & \multirow[b]{2}{*}{$\mathbf{P}$} \\
\hline & Mean & SD & Median & Mean & SD & Median & \\
\hline Age (years) & 64.7 & 5.2 & 63.0 & 63.2 & 3.5 & 62.5 & .7 \\
\hline 6MW (meters) & 402.0 & 71.5 & 423.0 & $424.7 \mathrm{t}$ & 80.2 & 449.0 & .5 \\
\hline MIP (cmH20) & 45.8 & 8.6 & 47.0 & 48.4 & 7.1 & 49.5 & .5 \\
\hline MEP (cmH20) & 58.3 & 12.9 & 64.0 & 65.2 & 7.4 & 68.0 & .3 \\
\hline STS (repetitions) & 10.6 & 1.7 & 11.0 & 11.1 & 1.7 & 11.5 & .5 \\
\hline
\end{tabular}

Note: Legend: $n=$ sample size; $S D=$ Standard Deviation; $p=$ significance level in U-Mann Whitney test; $6 M W=$ Six-minute walk test ; MIP= Maximal Inspiratory Pressure; MEP = Maximal Expiratory Pressure; $\mathrm{cmH} 20=$ centimeters of water; $\mathrm{STS}=$ Sit-to-Stand Test

\section{Discussion}

The results of the present study showed that elderly HD patients, when inserted into a physical exercise program, presented improvement in the covered distance at 6MW, in STS repetitions and in maximal respiratory pressures.

After six months of participation in the physical exercise program, the EG patients increased, in average, 64.8 meters in the covered distance at 6MW, which is considered very important for this population, since HD patients have a great decrease in functional capacity caused both by the disease and by the treatment (20). This increase in the covered distance is especially relevant, mainly in a population with high morbidity, since short distances (shorter than 300 meters) are strongly associated with morbidity and mortality (21).

The results of a study conducted with $14 \mathrm{New}$ Yorkers, aged between 31 and 78 years, agree with the results of the present research, in which three months of aerobic and resistance training during HD sessions obtained an increase in covered distance at 6MW (22). This improvement was highlighted in several review studies $(8,11,23)$, indicating that physical exercise brings positive effects to the functional capacity of HD patients.

The muscular system of CKD patients suffers several morphologic and physiologic alterations. Muscular atrophy and malnutrition are cited as factors that lead to muscular weakness (24), usually more observed in lower limbs. According to Reboredo et al. (25), such muscular force loss may be reverted with physical exercise practice, which was observed in the present study with the increase of LME (Local Muscular Endurance) of lower limbs, evaluated by the number of STS repetitions after 24 weeks of physical exercise in EG. The elderly had improvement in approximately 3.5 repetitions in STS.

The results of the present study are also in agreement with the findings of Painter et al. (26) (mean age of 54.3 years), in which patients carried out a similar physical exercise program, made up of aerobic, resistance and flexibility exercises. The authors observed significant reduction in the execution time on sit-to-stand movement five times from the chair. This reduction in the execution time in STS predicts death risk by all causes and improves the capacity of developing the basic activities of daily living (15).

Studies by Headley et al., (27) (mean age of 42.8 years), Chen et al. (28) (mean age of 69 years) and Segura-Ortí, Kouidi \& Lison, (29) (mean age of 55.6 years), which compared isolated effects of resistance training and Koufaki, Mercer \& Naish's study (30) (mean age of 53.9 years), which compared the isolated effects of aerobic training, also found an increase in the repetition number or, a reduction in execution time in STS. Such improvement may be attributed to the fact that physical exercise improves the muscular structure, the number of capillaries and mitochondria, which are responsible for getting oxygen (31), and the capacity of performing physical exercise (6).

One of the countless consequences of CKD, as well as the dialysis therapy, is pulmonary dysfunction. A study conducted in a renal clinic in the city of Ijuí, Rio Grande do Sul, with the objective of comparing the functional 
capacity and quality of life of CKD patients on $\mathrm{HD}(\mathrm{n}=27)$ and pre-dialysis therapy patients $(\mathrm{n}=27)$, identified that there was a decrease in the muscle respiratory strength (MIP and MEP) in both groups, but with greater impact on the group who already was on HD treatment (20). This dysfunction usually occurs due to circulant toxins or other factors such as volume overload, anemia, malnutrition and muscular weakness (32), causing countless physical and functional problems (20).

In the present study, respiratory muscle strength presented changes after the training period of approximately $7.6 \mathrm{cmH}_{2} \mathrm{O}$ in MIP and $13.9 \mathrm{cmH}_{2} \mathrm{O}$ in MEP. These data agree with those found by Coelho et al. (18) (mean age of 45.0 years), in which seven patients on HD, after an eight-week training, had an increase in MIP and MEP. Such improvement was also observed in a study with 22 patients (mean age of 42.1 years), of both genders, who underwent HD treatment for more than six months and took part in a physical exercise program (aerobic and resistance training) for 16 weeks (33).

The gain observed for this variable can be attributed to benefits promoted by physical exercise in the respiratory dysfunction, present in these patients, either due to the disease or HD therapy. The improvement in respiratory muscle strength may contribute to functional capacity by increasing the capacity to perform physical exercise, consequently, assisting in treatment and rehabilitation of these patients and improving their health and quality of life (17). Rehabilitation and treatment programs with specific exercises for respiratory muscle strength may contribute with the increase of covered distance at the 6MW test, bringing several benefits for patients on HD (34).

Besides the contribution of this study for the physical activity and health area, its data cannot be generalized for other patients, because it was conducted in only one clinic. This limitation did not affect the potential of the study, since it seems to be the first to analyze the effects of the regular practice of physical exercise on the functional capacity of elderly patients submitted to HD in a city of Rio Grande do Sul, Brazil.

\section{Conclusion}

The results of this study evidenced that physical exercise positively modifies functional capacity, as it increased the covered distance at the 6MW test, respiratory muscle strength and the number of STS repetition in HD patients.
Such data are extremely relevant for the health and physical activity area because, in addition to increasing functional capacity in elderly individuals on HD, they emphasized the importance of the physical education professional, together with all staff of the renal unit, for the rehabilitation and physical improvement of these patients.

Thus, it is recommended that physical exercise programs for patients on HD be encouraged and, mainly, inserted in sites of CKD care, as a way to help in their treatment and rehabilitation. Yet, further studies with this population are suggested, publishing benefits and consequences of this kind of intervention.

Other aspects that may interfere in the improvement / maintenance of physical capacity of these patients, such as health quality and clinical aspects, should be considered in further studies. Moreover, studies with a greater number of participants and with more than two evaluations are proposed.

\section{References}

1. Hirvensalo M, Lintunen T. Life-course perspective for physical activity and sports participation. Eur Rev Aging Phys Act. 2011; 8(1): 13-22.

2. Sesso RC, Lopes AA, Thomé FS, Lugon JR., Santos DR. Relatório do censo brasileiro de diálise de 2010. J Bras Nefrol. 2011; 33(4): 442-4.

3. Bastos MG, Bregman R, Kirsztajn GM. Doença renal crônica: frequente e grave, mas também prevenível e tratável. Rev Assoc Med Bras. 2010; 56(2): 248-53.

4. Medeiros RH, Pinent CEC, Meyer F. Aptidão física de indivíduo com doença renal crônica. J Bras Nefrol. 2002; 24(2) : 81-7.

5. Odden MC. Physical functioning in elderly persons with kidney disease. Adv Chronic Kidney Dis. 2010; 17(4): 348-57.

6. Casaburi R. Treinamento de Exercício Reabilitativo em Pacientes Submetidos à Diálise. In: Kopple JD, Massry SG, editor. Cuidados Nutricionais das Doenças Renais. Rio de Janeiro: Guanabara Koogan; 2004. p. 547-60.

7. Greenwood SA, Lindup H, Taylor K, Koufaki P, Rush $\mathrm{R}$, Macdougall IC, et al. Evaluation of a pragmatic exercise rehabilitation programme in chronic kidney disease. Nephrol Dial Transplant. 2012; 27 (Suppl 3):126-34. 
8. Johansen KL. Exercise and dialysis.Hemodial Int. 2008; 12(3): 290-300.

9. Johansen KL, Painter P. Exercise in individuals with CKD. Am J Kidney Dis. 2012; 59(1): 126-34.

10. Mustata S, Groeneveld S, Davidson W, Ford G, Kiland K, Manns B. Effects of exercise training on physical impairment, arterial stiffness and healthrelated quality of life in patients with chronic kidney disease: a pilot study. Int Urol Nephrol. 2011; 43(4) : 1133-41.

11. Coelho DM, Ribeiro JM, Soares DD. Exercícios físicos durante a hemodiálise: uma revisão sistemática. J Bras Nefrol. 2006; 30(2):88-98.

12. Soares KTA, Viesser MV, Rzniski TAB, Brum EP. Eficácia de um protocolo de exercícios físicos em pacientes com insuficiência renal crônica, durante o tratamento de hemodiálise, avaliada pelo SF-36. Fisioter Mov. 2011; 24(1): 133-40.

13. Lima FF, Miranda RCV, Rossi e Silva RC, Monteiro HL, Yen LS, Fahur BS, et al. Avaliação funcional pré e pós-programa de exercício físico de pacientes em hemodiálise. Rev Med USP. 2013; 46(1): 24-35.

14. Britto RR, Souza LAP. Teste de caminhada de seis minutos - uma normatização brasileira. Fisioter Mov. 2006 ; 19: 49-54.

15. Jones CJ, Rikli RE, Beam WC. A 30-s chair-stand test as a measure of lower body strength in communityresiding older adults. Res Q Exerc Sport. 1999; 70(2): 113-9.

16. Black LF, Hyatt RE. Maximal respiratory pressures: normal values and relationship to age and sex. Am Rev Resp Dis. 1969; 99(5):696-702.

17. Marchesan M, Rombaldi AJ. Programa de exercícios físicos para o doente renal crônico em hemodiálise. Rev Bras Ativ Fis e Saúde. 2012; 17(1): 75-8.

18. Coelho DM, Castro AM, Tavares HA, Abreu PCB, Glória RR, Duarte MH, et al. Efeitos de um Programa de Exercícios Físicos no Condicionamento de Pacientes em Hemodiálise. J Bras Nefrol. 2006: 28(3):121-7.

19. Borg G. Escalas de Borg para dor e esforço percebido. Manole: São Paulo; 2000.
20. Fassbinder TRC, Winkelmann ER, Schneider J, Wendland J, Oliveira OB. Capacidade funcional e qualidade de vida de pacientes com doença renal crônica prédialítica e em hemodiálise - Um estudo transversal. J Bras Nefrol 2015; 37(1): 47-54.

21. Gorkin L, Norvel NK, Rosen RC, Charles E, Shumaker AS, Mclntyre KM et al. Assessment of quality of life of observed from the baseline data of the studies of left ventricular dysfunction (SOLVD). Am J Cardiol. 1993; 71(12) : 1069-73.

22. Oh-Park M, Fast A, Gopal S, Lynn R, Frei G, Drenth R, et al. Exercise for the dialyzed: Aerobic and strength training during hemodialysis. Am J Phys Med Rehabil. 2002; 81(11) : 814-21.

23. Böhm J, Monteiro MB, Thomé FS. Efeitos do exercício aeróbio durante a hemodiálise em pacientes com doença renal crônica: uma revisão da literatura. J Bras Nefrol. 2012; 34(2): 189-94.

24. Adams GR, Nosratola DV. Skeletal muscle dysfunction in chronic renal failure: effects of exercise. Am J Phys Renal Physiol. 2006; 290(4) : F753-61.

25. Reboredo MM, Henrique DMN, Bastos MG, de Paula RB. Exercício físico em pacientes dialisados. Rev Bras Med Esp. 2007; 13(6): 427-30.

26. Painter P, Carlson L, Carey S, Paul SM, Myll J. Physical functioning and health-related quality-of-life changes with exercise training in hemodialysis patients. Am J Kidney Dis. 2000; 35(3): 482-92.

27. Headley S, Germain M, Mailloux P, Mulhern J, Ashworth B, Burris J, et al. Resistance training improves strength and functional measures in patients with endstage renal disease. Am J Kidney Dis. 2002; 40(2): 355-64.

28. Chen JLT, Godfrey S, Ng TT, Moorthi R, Liangos O, Ruthazer R, et al. Effect of intra-dialytic, low-intensity strength training on functional capacity in adult hemodialysis patients: a randomized pilot trial. Nephrol Dial Transplant. 2010; 25(6) : 1936-43.

29. Segura-Ortí E, Kouidi E, Lisón JF. Effect of resistance exercise during hemodialysis on physical function and quality of life: randomized controlled trial. Clin Nephrol. 2009; 71(5):527-37. 
30. Koufaki P, Mercer TH, Naish PF. Effects of exercise training on aerobic and functional capacity of endstage renal disease patients. Clin Physiol Funct Imaging. 2002; 22(2): 15-24.

31. Kouidi E, Albani M, Natsis K, Megalopoulos A, Gigis P, Guiba-Tziampiri 0 , et al The effects of exercise training on muscle atrophy in hemodialysis patients. Nephrol Dial Transplant. 1998;13(3):685-99.

32. Prezant DJ. Effect of uremia and its treatment on pulmonary function. Lung. 1990; 168: 1-14.

33. Marchesan M, Nunes VGS, Rombaldi AJ. Treinamento físico melhora a aptidão física e a qualidade de vida de pacientes em hemodiálise. Rev Bras Cineantropom Desempenho Hum. 2014; 16(3): 324-44.

34. Silva VG, Amaral C, Monteiro MB, Nascimento DM, Boschetti JR. Efeitos do treinamento muscular respiratório nos pacientes em hemodiálise. J Bras Nefro. 2011; 33(1): 62-8.

Received: 07/09/2014

Recebido: 09/07/2014

Approved: $10 / 08 / 2015$

Aprovado: 08/10/2015 
